\title{
Emosi Regret dan Pengambilan Keputusan dalam Bidang Ekonomi
}

\author{
Faraz Umaya ${ }^{1}$ \\ Program Pascasarjana Psikologi Universitas Mercu Buana Yogyakarta
}

\section{Pengantar}

Hari ini Vina dan Rahma mempunyai uang yang sama yaitu sebesar Rp 5 juta. Kemarin, Vina mempunyai uang Rp 7 juta, sementara Rahma mempunyai uang $\mathrm{Rp} 3$ juta. Apakah hari ini Vina dan Rahma mempunyai utilitas (kebahagiaan) yang sama? Dari kacamata ekonomi sesuai teori Bernoulli, ya mereka dipastikan mempunyai kebahagiaan yang sama. Tetapi kalau tidak dibutakan teori ekonomi, dan berbicara dengan perasaan, siapapun akan mengatakan hari ini Vina relatif kurang bahagia dibandingkan Rahma. Mengapa Vina kurang bahagia, karena kemarin kekayaan Vina lebih besar dari sekarang, sementara Rahma lebih bahagia karena kebalikannya. Kemampuan untuk merujuk kekayaan kemarin merupakan kekuatan yang muncul akibat respons emosi, dan utilitas perilaku ekonomi orang tergantung dari respons emosinya (Damasio, 1994; Kahneman, 2011).

Emosi menjadi kajian utama psikologi dalam tiga dekade terakhir. Para ahli mengakui emosi memainkan peranan penting dalam proses-proses psikologi, seperti: "learning, attention, dan memory" (Izard et al., 1984; Lewis \& Haviland-Jones, 2000, dalam Bosman, Sonnemans \& Zeelenberg, 2001). Emosi tidak hanya berguna membentuk preferensi tetapi juga mempunyai kekuatan mempengaruhi pembuatan

\footnotetext{
${ }^{1}$ Korespondensi mengenai artikel ini dapat melalui: umarmoyo@yahoo.com
}

keputusan (Ester 1998, dalam Bosman, Sonnemans \& Zeelenberg, 2001). Perasaan bahagia, sedih dan marah mewarnai dan membentuk keputusan seseorang (Mellers, Schwartz \& Ritov, 1999). Ketika suasana hati baik (good mood) maka akan lebih baik dalam mengatasi masalah (Isen, 1984, 1987,1993, dalam Mellers, Schwartz \& Ritov, 1999 ). Banyak orang menggunakan emosi untuk membantunya mengambil keputusan yang terbaik (Mellers dan McGraw, 2001). Ahli pemasaran telah lama mengetahui bahwa perilaku konsumen sangat dipengaruhi mood-nya (Han, Lerner \& Keltner, 2007). Menurut Slovic, Finucane, Peters dan MacGregor (dalam Zeelenberg dkk., 2008), emosi berfungsi melengkapi keterbatasan kognitif dalam membuat keputusan.

Peran emosi lebih detail dapat dideskripsikan sebagai berikut: 'Sepanjang proses pengambilan keputusan, emosi muncul dan berperan mempengaruhi tahap-tahap pengambilan keputusan'. Pada tahap sesudah memutuskan tetapi belum mengetahui hasilnya, emosi yang muncul adalah "harap dan takut" (hope dan fear). Pada tahap ini rasanya ingin sekali mencari tahu bagaimana hasil keputusannya dan berharap yang terbaik (Zeelenberg dkk., 2008). Pada tahap yang sama, tidak jarang dari kita justru ingin menghindar dari informasi karena takut hasilnya tidak memuaskan. Pada tahap sudah diketahui hasilnya, emosi yang muncul untuk hasil yang tidak puas ada- 
lah regret dan disappointment, untuk hasil yang puas adalah elation, happiness, dan surprise (Zeelenberg, dkk., 2008). Lalu, apa implikasinya ketika seseorang menghadapi sebuah emosi takut atau harap? Zeelenberg dan Pieters (2006), melalui pendekatan feeling is for doing, mengemukakan bahwa emosi berfungsi sebagai motivasi. Contoh: orang yang dihinggapi rasa takut ia akan termotivasi untuk lari dan menjauh dari objek sumber rasa takut itu, sebaliknya orang yang berharap akan termotivasi mendekat objek yang menjadi harapannya.

Pfister dan Bohm (2008) mengatakan fungsi yang dimainkan emosi dalam pengambilan keputusan tidaklah homogen. Menurut mereka, setidaknya, ada empat fungsi emosi. yakni: information, speed, relevance dan commitment. Pertama, dalam kondisi apapun sebuah keputusan membutuhkan information. Keputusan dibuat untuk memberikan kondisi yang lebih baik, kehadiran informasi sangat bermanfaat untuk melakukan evaluasi. Kedua, pengambilan keputusan adalah sesuatu yang integral dengan aktivitas manusia, dan karenanya akan banyak hambatan atau rintangan. Salah satu rintangan penting adalah menyangkut waktu atau tekanan waktu. Dalam konteks ini, peran emosi adalah memberikan speed agar pengambil keputusan dapat membuat keputusan secara cepat di bawah tekanan waktu. Ketiga, pengambil keputusan biasanya menyeleksi aspek-aspek tertentu yang menjadi perhatiannya. Proses seleksi ini dikendalikan oleh apa yang disebut relevance. Dalam konteks ini emosi berperan mengarahkan pengambil keputusan untuk memperhatikan aspek-aspek yang relevan saja. Keempat, suatu hal yang melekat pada pengambil keputusan adalah mengharapkan bahwa keputusan itu cukup dibuat sekali untuk digunakan dalam jangka waktu yang relatif lama. Dalam hal ini pada umumnya orang menunjukan commitment, khususnya dalam situasi pembuatan keputusan yang kompleks.

\section{Emosi dan "Somatic Marker Hypothesis"}

Damasio (1994) melakukan eksperimen tentang relasi emosi dan pengambilan keputusan dengan menggunakan metode mutakhir, yaitu: 'Somatic Marker Hypothesis'. $^{2}$ Kelebihan metode ini adalah mampu mendeteksi emosi yang muncul melalui perubahan pada fisik atau anggota tubuh. Perubahan dimaksud terjadi selama proses pengambilan keputusan, dan berfungsi memberikan tanda atau sinyal bagi pengambil keputusan mengenai pilihan mana yang menguntungkan dan mana yang tidak. Hasil penelitian Damasio mengemukakan bahwa tanpa keterlibatan emosi maka pengambilan keputusan tidak akan tercapai secara optimal (Naqvi, Shiv, \& Bechara, 2006).

Penelitian Damasio dilakukan pada sejumlah pasien yang didiagnosis mengidap penyakit disfungsi otak, khususnya yang mengalami kerusakan pada ventromedial prefrontal cortex (vmPFC) 3 . Pasien pengidap vmPFC gejalanya ditandai dengan ketidakmampuannya mengubah pilihan. Pasien pengidap disfungsi otak ini tidak dapat belajar dari kasus sebelumnya untuk mengambil keputusan yang lebih baik pada kasus berikutnya. Meskipun pengalaman memilih sebelumnya adalah negatif, mereka tetap melakukan keputusan yang sama, dan tidak mampu beralih ke pilihan lain yang lebih baik. Damasio (1994) menjelaskan bahwa pasien dengan diagnosis vmPFC sebenarnya secara

\footnotetext{
2 Suatu pendekatan yang memberikan penjelasan emosi melalui peran sel saraf otak.

${ }^{3}$ suatu area otak yang berlokasi di atas rongga mata, yang sering mengganggu kenyamanan seseorang.
} 
intelektual dan kemampuannya mengatasi masalah adalah normal. Persoalan yang dihadapi pasien vmPFC terletak pada ketidakmampuannya dalam menggunakan emosi untuk membantunya dalam proses pengambilan keputusan, terutama keputusan yang bersifat personal. Prinsip yang paling mendasar dari pendekatan 'somatic marker hypothesis' bahwa emosi memainkan peran dalam mengarahkan perilaku pengambilan keputusan.

Temuan Damasio ini dikembangkan Bechara (2004) dengan menggunakan instrumen pengukuran skin-conductance respons (SCR). Bechara menyebutkan bahwa bagi subjek (pasien) yang normal maka SCR-nya berjalan dengan baik. Cara kerja instrumen SCR adalah sebagai berikut: pertama, instrumen ini akan memberikan tanda atau sinyal respons yang besar ketika individu akan mengambil keputusan atau pilihan yang tidak menguntungkan. Sebaliknya, sinyal respons dari instrumen ini akan mengecil, ketika individu akan mengambil keputusan atau pilihan yang menguntungkan.

Cara kerja SCR dapat diilustrasikan bahwa setiap individu yang melakukan pilihan atau keputusan sesungguhnya mendapatkan pengawalan dari sistem "alarm", semacam "defense mechanism" dalam tubuh. Ketika pilihannya cenderung akan merugikan, maka "alarm" itu akan berbunyi kencang. Sebaliknya, ketika pilihannya cenderung menguntungkan, "alarm" tidak berbunyi. Bagi pasien pengidap vmPFC, fungsi SCR-nya tidak berjalan dengan baik, karena subjek sama sekali tidak memperlihatkan adanya antisipasi terhadap respons emosi.

Bechara dan Damasio (2004) berpendapat bahwa hasil temuan mereka dapat menjawab persoalan-persoalan pengambilan keputusan. Dalam bidang ekonomi, misalnya, bidang yang selama ini meng- abaikan faktor "emosi". Mereka menegaskan bahwa disiplin neuroscience saat ini sudah sangat maju. Salah satu temuan penting dari disiplin ini adalah bahwa pengambilan keputusan rasional perspektif ekonomi, kenyataannya, sangat tergantung dari tingkat akurasi dari proses emosi sebelumnya. Bila ada masalah dengan akurasi dalam proses emosi, maka pengambilan keputusan rasional tidak dapat dilaksanakan dengan baik.

\section{Emosi dan Kelemahan Teori Expected Utility}

Salah satu teori terkenal untuk menjawab fenomena pengambilan keputusan dalam kondisi ketidakpastian bidang ekonomi adalah expected utility theory (UET). Teori yang pertama kali dipopulerkan von Neumann dan Morgenstern pada tahun 1947 ini (Plous, 1993) berprinsip bahwa orang (konsumen) selalu akan berpikir rasional dan memaksimalkan keuntungan dalam mengambil keputusan. Teori ini, menurut pencetusnya, tidak dimaksudkan untuk mendeskripsikan bagaimana orang berperilaku sesungguhnya (deskriptif), melainkan bagaimana orang seharusnya berperilaku jika mereka mengikuti prosedur pengambilan keputusan rasional (normatif).

Kelemahan UET dalam menjelaskan perilaku pengambilan keputusan terletak pada pengabaiannya terhadap faktor "emosi". Fakta yang tidak bisa dibantah bahwa manusia tidak hanya rasional tetapi juga emosional. Hal ini diperkuat hasil temuan peraih Nobel Ekonomi 1978, Herbert Simon (1972, dalam Earl ed., 2001) dalam teorinya bounded rationality menyatakan bahwa kapasitas kognitif manusia itu terbatas. Manusia tidak mampu mengolah sekian banyak informasi (alternatif) yang seringkali bersifat "uncertanty". Kemudian ia merumuskan model pengambilan keputusan yang berpatok pada 
"satisfaction" (kepuasan). Keputusan tidak lagi memerlukan semua informasi untuk memilih mana yang terbaik dari yang ada, keputusan mungkin tidak optimal, tetapi cukup beberapa karakter penting yang dapat memberikan kepuasannya (Radner, 1975, dalam Earl ed., 2001).

Temuan tentang bounded rationality mengasumsikan bahwa banyak keputusan konsumen berpotensi tidak optimal. Menurut Zeelenberg dan Pieters (2007) setiap kali orang melakukan keputusan yang salah (kurang optimal) akan berimplikasi pada munculnya regret ${ }^{4}$. Satu atau dua frekuensi regret yang dialami konsumen mungkin dapat diatasi melalui sistem regulasi emosi, tetapi kalau ratusan bahkan ribuan sensasi regret muncul, maka sistem regulasi itu tidak dapat berjalan secara optimal. Schwartz (2004) menemukan bahwa akumulasi dari pengalaman regret yang dialami konsumen di Amerika telah membuat banyak masyarakat Amerika hidup dalam kondisi stres, jauh dari bahagia dan tidak sedikit yang mengalami depresi.

Kajian emosi regret tidak hanya menarik, tetapi juga penting dilakukan, karena sudah banyak bukti bahwa regret bukan hanya sekadar reaksi afektif dari hasil keputusan buruk, lebih dari itu, regret merupakan emosi yang memberi arah pada perilaku seseorang (Zeelenberg dan Pieters, 2007). Dengan kata lain, memahami emosi regret, tidak hanya berguna untuk memahami perilaku individu dalam mengambil keputusan, tetapi juga dapat menjadi semacam panduan dalam mengambil keputusan.

Dalam konteks Indonesia, kajian emosi regret menjadi lebih menarik, karena pihak produsen, toko retail besar maupun

\footnotetext{
${ }^{4}$ Dalam berbagai literatur regret dikategorikan sebagai "emosi negatif" dan dalam kamus InggrisIndonesia diterjemahkan "penyesalan".
}

kecil di Indonesia, pada umumnya kurang memperhatikan kondisi emosi konsumen, utamanya regret. Misalnya, sebuah produk yang sama seringkali mempunyai harga yang berbeda pada satu toko dengan toko lainnya, meskipun dalam satu pasar. Pada toko retail atau outlet, biasanya juga kita temukan tulisan seperti ini, "Barang yang sudah dibeli tidak dapat dikembalikan" atau "Memecahkan barang berarti anda membelinya". Kalimat-kalimat seperti ini tentu saja sangat berpotensi memunculkan regret konsumen.

\section{Emosi Regret dan Pengambilan Keputusan Ekonomi}

Definisi tentang regret relatif beragam. Perbedaannya tidak hanya terjadi antara pakar psikologi dengan pakar ilmu lain (ekonomi) yang turut mengembangkan, tetapi juga di kalangan peneliti psikologi sendiri. Namun, prinsip definisi regret yang diakui semua peneliti dapat dirumuskan sebagai berikut: regret merupakan jenis emosi yang muncul ketika konsumen meragukan kualitas dari produk yang ia pilih (beli), kemudian ia berpikir bahwa produk lain yang sebelumnya juga menjadi pertimbangan untuk dibeli (tetapi tidak jadi) mungkin saja (diketahui) mempunyai kualitas yang lebih baik. Jika pada kenyataannya benar bahwa produk (alternatif) yang tidak jadi dibeli mempunyai kualitas yang lebih baik, maka konsumen akan mengalami regret. Berpikir tentang "seandainya membuat keputusan yang berbeda" yang dipikirkan konsumen tesebut disebut counterfactual ${ }^{5}$, dan berpikir seperti

\footnotetext{
${ }^{5}$ Menurut kamus psikologi, dijelaskan arti counterfactual sebagai pernyataan atau hipotesis bersyarat yang bertentangan dengan fakta (Reber dan Reber, 2010, p.214). Dalam konteks teori regret, berpikir counterfactual dimaksudkan bahwa seseorang ketika menghadapi suatu fakta yang tidak menyenangkan, ia akan berpikir ke arah keadaan yang bertentangan dengan fakta. Misal,
} 
ini merupakan kecenderungan yang ada pada konsumen, yakni membandingkan antara hasil (outcome) dari keputusannya memilih dengan hasil dari apa yang mereka terima seandainya melakukan pilihan yang berbeda (Loomes \& Sugden, 1987).

Beberapa batasan regret yang dirumuskan para peneliti, antara lain: regret merupakan jenis emosi yang didasarkan sebuah perbandingan (Van Dijk \& Zeelenberg, 2002). Regret merupakan respons terhadap hasil keputusan buruk (Pieters \& Zeelenberg, 2005). Regret dikategorikan sebagai emosi kognitif, karena untuk memahami apakah konsumen mengalami regret atas keputusannya atau tidak, konsumen yang bersangkutan semestinya telah berpikir, baik tentang produk yang dipilih maupun produk yang tidak dipilih (Landman, 1993; Zeelenberg, 1999). Menurut teori justifikasi keputusan (decision justification theory), regret mempunyai dua komponen inti, yakni evaluasi (perbandingan) dari hasil keputusan dan perasaan bersalah pada diri (self-blame). Keduanya dapat secara bersama memunculkan regret, atau salah satu dari keduanya juga dapat memunculkan regret (Connolly \& Zeelenberg, 2002).

Regret muncul disebabkan adanya informasi mengenai produk yang tidak dibeli, yang mungkin lebih baik dibandingkan yang dibeli. Perbedaan pandangan mengenai teori regret antara pakar ekonomi dan psikologi terletak pada sumber informasi ini. Bagi ekonomi, regret hanya dapat muncul setelah adanya informasi (negatif) dari luar diri konsumen tentang produk yang tidak dibeli, sementara bagi psiko-

ketika seseorang memilih produk A, dan terbukti bahwa produk A tidak memberikan kepuasan pada dirinya, maka iapun secara otomatis akan berpikir counterfactual, dengan mengatakan "seandainya saja saya memilih produk B, mungkin akan memberikan kepuasan." logi, informasi itu tidak harus dari luar, karena bisa juga bersifat imajinasi dari memorinya.

Menurut Bell (1982), Loomes dan Sugden (1987), teori regret 6 dibangun berdasarkan dua asumsi. Pertama, pada dasarnya konsumen cenderung membandingkan antara hasil (outcome) dari keputusannya memilih dengan hasil dari apa yang mereka akan terima seandainya melakukan pilihan yang berbeda. Kedua, konsumen cenderung mengantisipasi regret sebelum membuat keputusan, karenanya seringkali mereka mengubah pilihan untuk menghindari potensi regret.

Dari dua kecenderungan ini, psikologi regret dapat dikaji baik sebagai anteseden maupun konsekuensi. Artinya, sensasi regret tidak hanya terjadi pasca keputusan, tetapi dapat juga diketahui sebelum konsumen melakukan keputusan. Sebelum mengambil keputusan disebut sebagai antisipasi regret, dan sesudah pengambilan keputusan disebut regret sebagai konsekuensi.

Regret sebagai Antisipasi. Konsumen, dalam mengambil keputusan, tidak hanya berusaha untuk memaksimalkan keuntungan dari produk yang akan dibeli, tetapi juga ia akan memilih pilihan yang dapat menghindarinya dari emosi negatif (Simonson, 1992). Bul Bul dan Meyvis (2006) mengatakan bahwa antisipasi regret atau upaya untuk meminimalisir regret merupakan kasus yang sering muncul dalam pengambilan keputusan konsumen. Konsumen pada dasarnya dapat mengan-

\footnotetext{
6 Teori regret merupakan pengembangan teori pengambilan keputusan dalam kondisi ketidakpastian sebelumnya, yakni teori prospek (prospect theory) dan teori kegunaan yang diharapkan (expected utility theory). Expected utility terkenal dengan konsep 'utility function', kemudian prospect theory terkenal dengan value function, dan teori regret terkenal dengan 'choiceless utility function'
} 
tisipasi mengenai perasaan yang muncul pasca keputusan, baik itu negatif atau positif (Ritov \& Baron, 1994). Peneliti lain mengemukakan bahwa pada dasarnya konsumen dapat mempelajari untuk memprediksi secara akurat berkaitan dengan regret yang akan dirasakannya (Mellers \& McGraw, 2001). Antisipasi regret juga banyak digunakan dalam pertimbangan pengambilan keputusan oleh konsumen (Simonson, 1992).

Penelitian tentang antisipasi regret, dalam literatur, lebih banyak berkaitan dengan masalah waktu. Misalnya, membeli lebih awal dapat saja menimbulkan regret karena dapat kehilangan peluang lebih baik di kemudian hari, atau sebaliknya membeli di akhir waktu, juga dapat menimbulkan regret karena ternyata peluang di awal lebih baik. Mana yang lebih regret antara membeli sekarang atau kemudian apabila hasilnya sama-sama negatif? Kondisi yang diasumsikan akan lebih regret adalah membeli pada waktu kemudian, karena akan mempunyai dua beban psikologis, yaitu beban terhadap kemungkinan hasil keputusannya buruk dan beban karena sudah menunggu lama (Cooke, Meyvis, \& Schwartz, 2001).

Antisipasi regret juga dikaji berkaitan dengan pilihan terhadap dua produk (barang dan jasa) yang berisiko dan tidak berisiko. Produk tidak terkenal, berkualitas rendah dan murah dikategorikan sebagai produk berisiko, sebaliknya produk terkenal, berkualitas bagus, tetapi mahal dikategorikan sebagai produk tidak berisiko. Teori regret mengajarkan, dalam kondisi serba tidak pasti, sebaiknya memilih produk yang tidak berisiko, berkualitas bagus meskipun mahal. Ketika konsumen memilih produk dengan merek terkenal, secara tidak langsung ia telah melimpahkan sebagian perasaan tanggungjawabnya (responsibilitas) kepada merek terkenal itu, sehingga seandainya keputusannya salah, tentu beban psikologisnya tidak terlalu berat.

Regret sebagai Konsekuensi. Tsiros dan Mittal (2000) mengembangkan sebuah model regret yang dialami (experienced regret) atau sebagai konsekuensi, lengkap dengan skala pengukuran dan juga membedakan antara regret dengan kepuasan (satisfaction). Tsiros dan Mittal mendefinisikan regret pasca keputusan sebagai respons emosional yang berasal dari perbandingan antara kualitas produk yang dipilih dengan kualitas produk yang tidak dipilih. Berdasarkan definisi ini, regret merupakan diskonfirmasi dari sebuah harapan, yang menurut Tsiros dan Mittal mirip dengan konsep "satisfaction". Namun, mereka menjelaskan bahwa regret dan satisfaction merupakan dua konstruk yang terpisah. Regret itu merupakan hasil perbandingan antara satu produk dengan produk lain, sementara kepuasan merupakan hasil perbandingan antara produk yang dibeli dengan harapannya semula tentang kualitas produk yang dimaksud.

Contoh regret sebagai konsekuensi. Bram, setelah melakukan banyak pertimbangan, memilih sebuah produk laptop merek " $X$ ". Laptop yang baru dibelinya itu ternyata memenuhi apa yang menjadi harapannya semula, yakni penampilannya menarik, sangat cepat dalam operasional dan ringan dibawa. Bram pun merasa puas (satisfaction) dengan keputusan membeli laptop merek " $X$ " itu. Tetapi satu bulan kemudian ia bertemu dengan Andi teman lamanya, kebetulan Andi mempunyai laptop sama persis dengan milik Bram. Harga laptop yang dibeli Bram Rp 200 ribu lebih mahal dari laptop Andi. Informasi tentang harga laptop Andi yang lebih murah ini membuat Bram mengalami regret, karena keputusannya kurang optimal. Kalau saja dia membeli di toko 
yang sama dengan Andi, maka ia akan menghemat Rp 200 ribu. Pikiran Bram terakhir ini disebut berpikir counterfactual.

Emosi regret muncul bisa beragam faktornya. Bram mungkin tidak bertemu dengan Andi dan tidak ada informasi apapun yang membandingkan dengan laptop yang baru dibelinya, tetapi setelah tiga bulan ia menggunakan laptop itu tibatiba rusak, kecepatan operasionalnya berkurang. Bram membawanya ke toko untuk diservis karena mendapatkan garansi satu tahun. Bram mendapatkan pelayanan servis gratis. Teknisi toko itu menjelaskan bahwa tipe laptop yang dimiliki Bram itu kelemahannya ada pada hardware-nya mudah panas bila digunakan lebih dari lima jam dan mudah mengalami "hang". Mendengar penjelasan teknisi itu, Bram pun mengalami regret, karena ia merasa telah memilih tipe yang salah. Lagi-lagi regret muncul disebabkan oleh keputusan yang kurang optimal. Pengalaman Bram, menurut Schwartz (2000) maupun Zeelenberg dan Pieters (2007), merupakan kecenderungan yang juga dialami oleh setiap konsumen.

\section{Regulasi Emosi Regret}

Beban psikologi regret seringan apapun seyogyanya tidak diabaikan mengingat akumulasinya sangat membahayakan kondisi subjective well-being seseorang (Schwartz, 2000). Zeelenberg dan Pieters (2007) merumuskan strategi bagaimana kita dapat mengurangi atau menghindari pengalaman tidak nyaman bernama "regret". Melalui teorinya "regulasi regret" mereka menjelaskan bahwa orang dapat mencegah regret yang akan dialaminya "mendatang" yakni dengan, antara lain, mentransfer atau membagi tanggung jawab (responsibility) atas keputusannya. Contoh: ketika orang dihadapkan pilihan antara membeli produk yang murah, tidak terkenal dan berpenampilan tidak menarik dengan produk yang menarik, terkenal tetapi mahal, maka sangat dianjurkan, untuk menghindari regret, memilih yang terkenal meskipun mahal. Dengan memilih produk yang terkenal ini secara tidak langsung telah mentransfer responsibility atas keputusannya, sehingga bila keputusannya salah atau tidak optimal, ia tidak akan mengalami rasa "regret" yang mendalam karena ia akan meyakinkan diri dan orang lain bahwa keputusannya sudah benar yakni memilih yang berkualitas, kalau yang berkualitas juga tetap rusak, maka hal itu diluar kemampuannya (tanggungjawabnya). Hal ini juga dapat menjelaskan mengapa banyak orang lebih suka membeli mobil baru daripada membeli mobil "second" meskipun secara finansial jauh lebih menguntungkan mobil "second". Membeli mobil baru relatif rendah regret yang akan dialami bila mengalami kerusakan dibandingkan membeli mobil "second" juga mengalami kerusakan. Emosi regret itu sangat terkait dengan konsep responsibility.

Bagaimana dengan emosi regret yang sedang dialami karena keputusannya kurang optimal. Regulasi regret menganjurkan beberapa strategi. Pertama dengan mengembalikan (undo) keputusan. Misal mengembalikan barang yang sudah dibeli selama bisa ditukarkan. Persoalannya budaya di Indonesia masih sangat sulit untuk melakukan hal ini. Kedua, melakukan justifikasi diri terhadap keputusan yang salah. Misalnya dengan mengatakan: "yang penting saya sudah mencoba dan tidak percuma, maklum saya tidak tahu, kalau saya tahu pastilah akan mengambil keputusan yang berbeda." Ketiga, menolak tanggung jawab. Misalnya, Bram melakukan kesalahan membeli tipe laptop, maka dia akan mengatakan kepada dirinya dan orang lain, "Ini kesalahan penjaga toko yang kurang 
ahli, mengapa dia tidak menginformasikan kepada saya kalau tipe laptop " $X$ " itu mempunyai karakter yang tidak tahan panas." Bram juga bisa menyalahkan penjaga toko langsung, "Kenapa mas ( $m b a^{\prime}$ ) tidak memberitahu saya sebelumnya". Strategi-strategi ini dipastikan dapat mengurangi beban emosi regret siapapun yang mengalaminya.

\section{Daftar Pustaka}

Bechara, A. (2004). The role of emotion in decision making: evidence from neurological patients with orbitofrontal damage. Brain and Cognition, 55, 30-40.

Bechara, A., \& Damasio, A. R. (2004). The somatic marker hypothesis: A neural theory of economic decision, Games and Economic Behavior, 52, 336-372

Bell, D. E. (1982). Regret in decision making under uncertainty. Operation Research, 30(5), 961-981.

Bosman, R., Sonnemans, J., \& Zeelenberg, M. (2001). Emotions, Rejections and Cooling of in the Ultimatum Game. (Manuskrip tidak Dipublikasikan).

Bulbul, C., \& Meyvis, T. (2006). When consumer choose to restrict their option: anticipated regret and choice set size preference. Journal of Consumer Research, 27, 151-172.

Cookie, A.D.J., Meyvis, T., \& Schwartz, A. (2001). Avoiding future regret in purchase-timing decisions. Journal of Consumer Research, 27, 447-459

Connolly, T., \& Zeelenberg, M. (2002). Regret in decision making. American Psyhological Society, 11(6), 212-216

Damasio, A.R. (1994). Descartes' error: Emotion, reason and humand braind. New York: Putnam.

Han, S., Lerner., J., \& Keltner, D. (2007). Feeling and consumer decision making: the appraisal-tendency framework. Journal of Consumer Psychology, 17(3), 158-168.

Kahneman, D. (2011). Thinking, Fast and Slow. New York: Farrar, Straus and Giroux.

Landman, J. (1987). Regret: a theoretical and conceptual analysis. The Theory of Social Behaviour, 17(2), 135-160.

Loomes, G., \& Sugden, R. (1987). Testing for regret and disappointment in choice under uncertainty. The Economic Journal, 97, 118-129.

Mellers, B., \& McGraw, A. P. (2001). Anticipated emotions as guides to choice. American Psychology Society, 10(6), 210-214.

Mellers, B., Schwartz, A. \& Ritov, D. (1999). Emotion-Based Choice. Journal of Experimental Psychology, 3, 332-345

Naqvi, N., Shiv, B., \& Bechara, A. (2006). The role of emotion in decision making: a cognitive neuroscience perspective. Psychological Science, 15(5), 260-264.

Pfister, H-R., \& Bohm, G. (2008). The multiplicity of emotions: a framework of emotional functions in decision making. Judgment and Decision Making, $3(1), 5-17$.

Pieters, R., \& Zeelenberg, M. (2005). On bad decision and deciding badly: when intention behavior inconsistency is regrettable. Organizational Behavior and Human Decision Processes, 97, 18-30.

Plous, S. (1993). The Psychology of Judgment and Decision Making, New York: McGraw-Hill, Inc.

Radner, R. (2001). Satisfaction. In Peter E. Earl (Ed), The legacy of Herbert Simon in Economic Analysis (pp.67-76). Cheltenham: Edwar Elgar Publishing Limited. 
Reber A. S., \& Reber, E. S. (2010). Kamus Psikologi (terj.). Yogyakarta: Pustaka Pelajar.

Ritov, I., \& Baron, J. (1994). Outcome knowledge, regret dan omission bias. Organizational Behavior and Human Decision Processes, 64, 119-127.

Schwartz, B. (2004). Tyranny of choice. Scientific American, April. 23-29.

Simon, H. A. (2001). Theories of bounded rationality. In Peter E. Earl (Ed), The legacy of Herbert Simon in Economic Analysis (pp.51-66). Cheltenham: Edwar Elgar Publishing Limited.

Simonson, I. (1992). The influence of anticipating regret and responsibility on purchase decisions. Journal of Consumer Research, 19, 105-118.

Tsiros, M., \& Mittal, V. (2000). Regret: a model of its antecedent and consequences in consumer decision making. Journal of Consumer Research, 26, 401417. van Dijk, W. W., \& Zeelenberg, M. (2002). Investigating the appraisal pattern of regret and disappointment. Motivation and Emotion, 26(4), 321-331.

Zeelenberg, M. (1999). Anticipated regret, expected feedback and behavioral decision making. Journal of Behavioral Decision Making, 12, 93-106.

Zeelenberg, M., Nelissen, R. M. A., Breugelmans, S. M., \& Pieters, R. (2008). On emotion specificity in decision making: why feeling is for doing. Judgment and Decision Making, 3(1), 1827.

Zeelenberg, M., \& Pieters, R. (2007). A theory of regret regulation 1.0. Journal of Consumer Psychology, 17(1), 3-18.

Zeelenberg, M., \& Pieters, R. (2006). Feeling is for doing: a pragmatic approach to the study of emotions in economic behavior. In Cremer, D De, Zeelenberg, M., \& Murnighan (Ed.), Social Psychology and Economics (pp.117-137). 